\title{
Responses of Populus deltoides' stem cuttings under treatment of different growth hormones in planting seasons
}

\section{Satyen Chhetri}

School of Agriculture, Forestry and Fisheries, Himgiri Zee University, P.O. Sherpur, Chakrata Road, Dehradun-248197 (Uttarakhand), India

\section{Sharad Pandey}

School of Agriculture, Forestry and Fisheries, Himgiri Zee University, P.O. Sherpur, Chakrata Road, Dehradun-248197 (Uttarakhand), India

Dharmveer*

School of Agriculture, Forestry and Fisheries, Himgiri Zee University, P.O. Sherpur, Chakrata Road, Dehradun-248197 (Uttarakhand), India

*Corresponding author. Email: dharmveer.kaintura2@gmail.com

\section{How to Cite}

Chhetri, S. et al. (2021). Responses of Populus deltoides' stem cuttings under treatment of different growth hormones in planting seasons. Journal of Applied and Natural Science, 13(1): 238 - 249. https://doi.org/10.31018/jans.v13i1.2530
Article Info

https://doi.org/10.31018/ jans.v13i1.2530

Received: January 27, 2021

Revised: March 2, 2021

Accepted: March 6, 2021

\begin{abstract}
The farmers have widely used vegetative propagation of plants due to the low germination percentage of seeds of various plant species. So to study the asexual propagation technique of Populus deltoides, the present study was conducted where a number of stem cuttings of Poplar were treated with growth hormones: IBA (Indole-3-butyric acid), NAA (1-Naphthaleneacetic acid) and GA3 (Gibberellic acid) at different concentrations (100 ppm, 200 ppm and 300 ppm). Some cuttings, which were not treated with hormones, considered as control. A completely randomized design was used to conduct the experiment. The responses were recorded for the cuttings, which were collected and planted in on-season (February) and off-season (July) for 30, 60 and 90 Day after planting (DAP). The results showed that the cuttings collected and planted in February month responded with the better growth rate in shoot and root parameters. The untreated cuttings showed relatively lower values for all growth parameters than the cuttings treated with hormones. Tukey HSD test of multiple comparisons revealed that IBA, at higher concentration, had significantly $(P<0.05)$ higher values for most of the growth parameters, followed by GA3. Pearson product-moment correlation showed a very strong correlation $(P>0.70)$ recorded for underground biomass and other parameters. These findings can allow the farmers to select the best treatment to enhance the growth and yield of $P$. deltoides.
\end{abstract}

Keywords: Growth hormones, Planting season, Poplar, Stem cutting, Vegetative propagation

\section{INTRODUCTION}

Poplars (Populus deltoids Bartram ex Marshall) belong to genus Populus species and family Salicaceae, and were introduced in India way back in 1950 and studies have been done on their yields at various places (Fotidar, 1979, Burgess et al. 2005, Dillen et al. 2013, Truax et al. 2014). In India, about 225 clones of various poplars have been introduced, tested and some of them have performed very well (Chauhan et al., 2008). The wood of Poplar is used for agricultural implements, cooling pads employed in room-coolers and sports goods (Rajput, 1996). The bark is used as a tonic, stimulant and blood purifier. Besides their economic importance, poplars are also preferred by farmers because of their short rotation, thus ensuring quick re- turns. The dependence of Indian matchwood and plywood industry on poplars is noteworthy and use of poplar leaves as fodder and fuel wood are also not rare (Singh, 1979; Singh and Singh, 2018).

P. deltoides, commonly called as Poplar, make up the backbone of agro-forestry in India (Kumar et al, 1999, Chavan and Dhillon, 2019). Large-scale plantation for poplar species is done for $P$. deltoides in India. The Poplar has contributed in agro-forestry land-use system appreciably to increase the tree cover outside natural forests as well as proved to be a potential resource for socio-economic development, ecological restoration and diversification of agriculture (Chauhan et al.2012). $P$. deltoides adapts well in the Indian ecological conditions than other species and hybrids (Cortizo et al. 2008). Poplar generally grows well in fertile alluvial 
soils. Poplar trees flourish in the clayey, sand and sandy loamy soil, humid rich, fine drained and soils near to the water resources with pH of 6.5-8.0 (Singh and Singh, 2018).

Cloning or vegetative propagation of the trees has been a constructive tool in traditional tree improvement, with the promising feature of clones being important for production forestry (Libby, 1986; Henrique et al., 2006). Implementation of clonal forestry has been successful in several hardwood species, particularly in eucalyptus, popular and willow (Zsuffa et al. 1993; Rezende et al. 2013) due to being a short rotation crop. Propagation of Poplar is widely increasing worldwide for the production of timber and raw materials for industrialization. Sexual propagation may be practised by farmers or the government but vegetative propagation is successful in terms of propagation and mass multiplication of Poplar. Vegetative propagation has become the preferred method of propagation to maintain individual characteristics, resulting in a genetically identical plant to the original donor plant (Araya 2005; Spriggs and Dakora 2007; Bester 2013).

The growth regulators have successfully been used by many researchers to increase the growth of stem cuttings of plant species (Soundy et al., 2008; Singh et al. 2011; Sağlam et al. 2014). Meanwhile, the collection and planting timing of stem cuttings has also affected the rooting of stem cutting. The present study was conducted to observe the effect of different growth hormones on various growth parameters of $P$. deltoides and find out the suitable planting season (February or July) for the same.

\section{MATERIALS AND METHODS}

The experiment was conducted to determine the effects of growth hormones on the growth parameters of cuttings $P$. deltoides $\mathrm{L}$. Marsh, under nursery conditions in the forest nursery and research centre, Department of Forestry and Fisheries, Himgiri Zee University, Dehradun (Fig. 1) in the year 2018. The climate of the region was broadly humid subtropical, with cold winter and hot dry summer. The district Dehradun is microgeographic area covering $3088 \mathrm{sq}$. km, located at between $29^{\circ} 55^{\prime}$ to $30^{\circ} 30^{\prime} \mathrm{N}$ and $77^{\circ} 35^{\prime}$ to $78^{\circ} 24^{\prime} \mathrm{E}$. Geographically, the district Dehradun is surrounded by the lesser Himalaya mountain on the north, Shivalik hills on the south and the river Ganga on south-east and the river Yamuna on the north-west. Its elevation ranges from 315 to $2500 \mathrm{~m}$ and the gradient varies between 7 and $10 \mathrm{~km}$. The area receives $137.3 \mathrm{~cm}$ to $188.6 \mathrm{~cm}$ rainfall annually, depending upon other climatic factors. In general, the temperature varies with the maximum range of $16^{\circ} \mathrm{C}$ to $36^{\circ} \mathrm{C}$ in summer (April to July) and $2^{0}$ $\mathrm{C}$ to $24^{\circ} \mathrm{C}$ in winter (November to February). Most of the part of the valley is plain and riverine. The water bodies of the Doon Valley form a Bioresourceenvironment by maintaining a balanced ecosystem. Although the climate varies, it is up to a considerable range. Hence flora and fauna of the valley seem to be transient between the sub-montane region and the Gangetic plains.

The stem cuttings of $P$. deltoides were selected for the study to check the effect of different growth regulators viz: IBA, NAA, and $\mathrm{GA}_{3}$ (purchased from the certified company) on its different growth parameters. Each growth regulator was prepared in three different concentrations: 100 ppm, 200 ppm and 300 ppm (Ullah et al., 2013). One experiment was also conducted in a control condition with no treatment applied. The treatments were distributed as T1: No Treatment; T2: IBA 100ppm; T3: IBA 200 ppm; T4: IBA 300 ppm; T5: NAA 100ppm; T6: NAA 200 ppm; T7: NAA 300 ppm; T8: GA3 100ppm; T9: GA3 200 ppm; T10: GA3 300 ppm

Stem cutting of plant species ( $P$. deltoides) of about 15 $\mathrm{cm}$ long and having at least 3 internodes were used as the planting material. The basal portion of the cutting was cut off and dipped into the distilled water for 24 hour (Haider et al., 2015). The cuttings were treated with the treatments for at least 10 minutes (Chauhan et al., 2015) and planted using a completely randomized design (CRD) with 3 replications. Each replication was having 3 numbers of cuttings. The experiment was conducted in the on-season (February) and off-season (July) of planting. Thus, a total 180 cuttings were utilized by the experiment in both seasons of planting. The cuttings were planted in an open condition in the nursery raised beds at $15 \mathrm{~cm} \times 15 \mathrm{~cm}$ spacing. The data for various growth parameters were recorded in 30,60 and $90 \mathrm{DAP}$.

\section{Determination of growth parameters}

The following parameters were taken into consideration for the assessment of cuttings of the different stem as a result of the growth regulator. Shoot length $(\mathrm{cm})$ was measured from the root collar to the terminal bud base using measuring rod/metallic tape. The cuttings were removed from the ground without any damage and the number of roots per cutting was counted along with the length of the root. The leaves were removed from the cutting without any damage to the plant and the number of leaf/ cutting was counted. The Shoot diameter was measured using a digital Calliper. The fresh shoot and root weight for each cuttings was taken separately by using an electronic tap pan balance; fresh root and shoot were dried at $60^{\circ} \mathrm{C}$ in an oven over 24 hours as per treatment and replication wise till constant weight was attained. Dry root and shoot weight (gm) were recorded using Electronic top pan balance.

\section{Statistical analysis}

The experiment was laid out in Completely Random- 


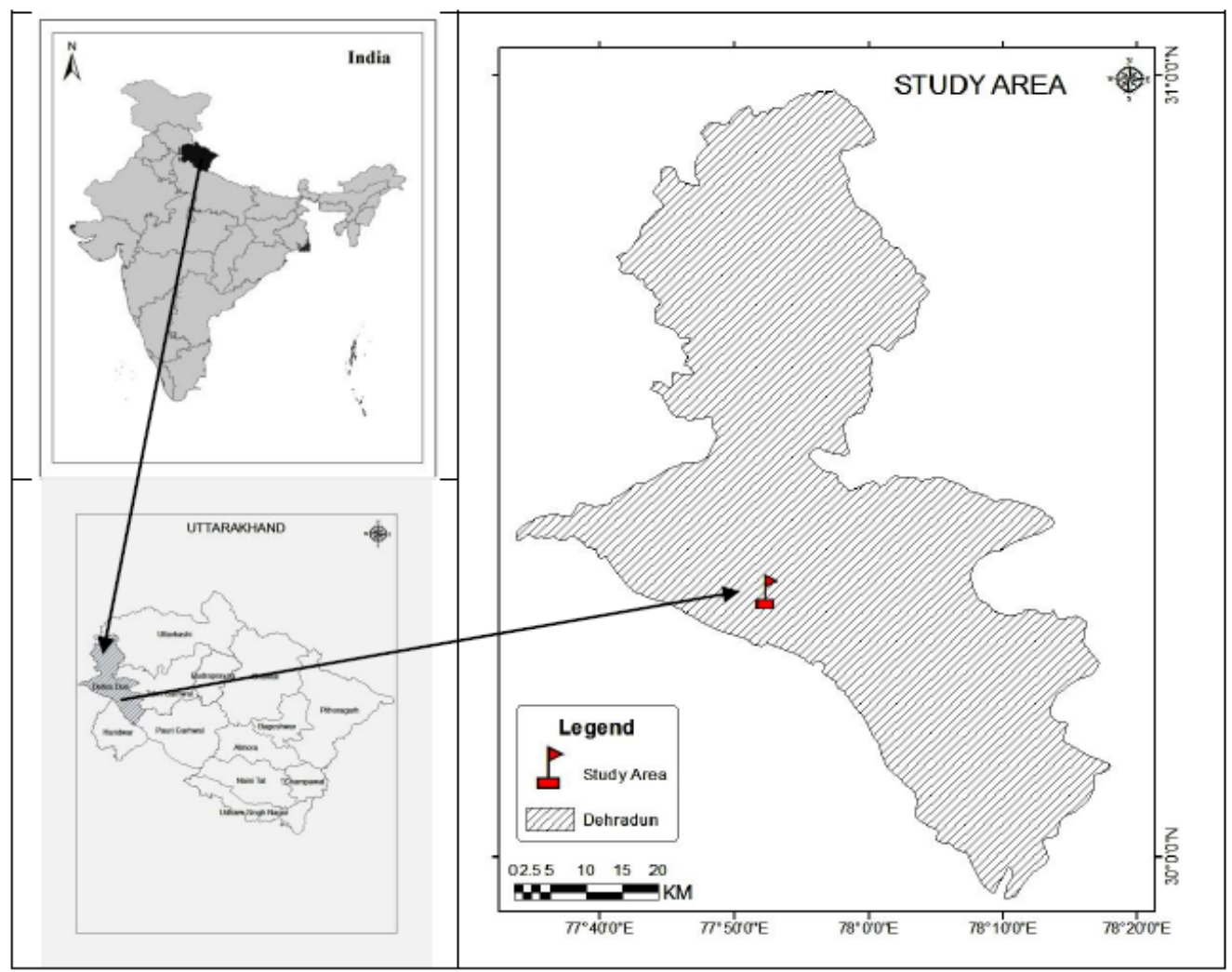

Fig. 1. Map of experimental site and study area at the nursery of Department of Forestry and Fisheries, Himgiri Zee university, Dehradun, Uttarakhand, India

ized Design having 10 treatments (including one control) with each replicated thrice. A multivariate ANOVA (Analysis of Variance) was used to test the significance at $5 \%$ level as well as $1 \%$ among different treatments and seasons of planting. For multiple comparisons, the Tukey HSD Post Hoc Test was used to test the difference between different treatments. Pearson productmoment correlation coefficient was calculated to analyse the relationship among different growth parameters. IBM SPSS V 21 was used for statistical analysis and Minitab Version 19 (Trial Version) was used for graphical representations.

\section{RESULTS}

Effect of various growth regulators on different growth parameters of $\boldsymbol{P}$. deltoides in 30 DAP in two different seasons of planting

In the present study, on-season planting, the analysis showed a significant effect $(P<0.001)$ on all the growth parameters (Table 1). The analysis of the multiple comparisons of various treatments, Tukey HSD test showed that there were statistically same values of number of sprouting and sprouting length in all treatments except in the control conditions, which showed relatively lower value as compared to others.

IBA, with 300ppm, showed consistently higher values after 30 days of planting for the number of leaves, the number of roots/cutting, root length/cutting, fresh weight of shoot, dry weight of root and shoot diameter (at par with GA3 $100 \mathrm{ppm}$ ). The values of all the parameters were recorded significantly lower in control conditions. The highest fresh root weight $(0.821 \mathrm{gm})$ was recorded for the cuttings treated with GA3 300 ppm, which was significantly $(P<0.05)$ higher than the values observed in other treatments.

In off-season planting, the treatments were overall having a significant effect $(P<0.001)$ on all the parameters. For most of the parameters (No. of sprouting, No. of leaves, sprouting length, no. of the root, root length and fresh weight of shoot), IBA 300 ppm showed the maximum values which was also at par with the values under other treatments. GA3 300 ppm had relatively higher values for fresh weight of root $(0.704 \mathrm{gm})$. The cuttings which were not treated with any growing media showed the least values of all the parameters.

When comparing the growth response of Poplar in two different seasons, the results showed significantly higher $(P<0.01)$ values for all the parameters except for dry weight of root, which did not differe significantly in two different seasons (Table 2).

\section{Effect of various growth regulators on different growth parameters of $P$. deltoides in 60 DAP in two different seasons of planting}

Data for different parameters recorded after 60 days of 
lanting showed a significant effect $(P<0.01)$ of various treatments in all growth parameters. The multiple comparisons showed many statistical at par values with the maximum value of different parameters. The number of sprouting (3.150), dry weight of root $(0.350 \mathrm{gm})$ and shoot diameter $(0.071 \mathrm{~cm})$ were relatively higher in the cuttings which were treated by IBA 300 PPM, which was statistically at par with other treatments (Table 3 ). The cuttings, which were planted in control conditions, showed relatively lower values for all parameters compared to the cuttings treated with the growth hormones. In off season planting, all treatments were overall having a significant effect $(P<0.01)$ on various parameters excluding shoot diameter, which showed a nonsignificant response $(P>0.05)$ after 60 days of planting. The no-treatment (control) cuttings showed consistently lower values for all parameters. Other than that, most parameters were having statistically $(P>0.05)$ same values under different treatments (based on post hoc test). Fresh weight of root and dry weight of shoot showed the same responses as showed in 30 DAP. Root length $(3.862 \mathrm{~cm})$ and fresh weight of shoot $(1.774 \mathrm{gm})$ showed relatively higher values under IBA 300 PPM. The planting season was also having a significant effect $(P<0.01)$ on different parameters (Table 4 ), which showed that the cuttings planted in on-season were having relatively higher values for all the parameters after 90 days of planting.

\section{Effect of various growth regulators on different growth parameters of $P$. deltoides in 90 DAP in two different seasons of planting}

In on-season planting, all the parameter showed a significant difference $(P<0.05)$ under various treatments after 90 days of planting (Table 5). The cuttings planted with no-treatment showed relatively lower values for all parameters. Other than that, based on the Tukey HSD test, the values of most of the parameters did not differ significantly $(P>0.05)$ under different treatments. Dry weight of shoot $(1.009 \mathrm{gm})$ was recorded significantly higher $(P<0.05)$ in the cuttings treated with IBA 100 ppm. In off-season planting, the growth response of poplar cuttings was also same under different treatment as in on-season planting for some parameters (Table 5). IBA $300 \mathrm{ppm}$ for fresh weight of shoot (2.276 gm); GA3 300 $\mathrm{ppm}$ for fresh weight of root $(1.059 \mathrm{gm})$ and IBA 200 for shoot diameter $(0.120 \mathrm{~cm})$ showed relatively higher values as compared to other treatments.

Comparison between two seasons of planting showed a significant difference $(P<0.01)$ for all parameters, excluding the number of roots, under different treatments (Table 6).

Trends of various parameters during 3 months of planting

In on-season, most of the parameters showed a rapid increase for the first sixty days. However, this increment slowed down when observed after 90 DAP (Fig. 2). This type of trend was the most common with the cuttings which were given no treatment. Under other treatments, some parameters (fresh weight of root, dry weight of root and shoot) showed an increasing trend of values after 60 DAP (Fig. 2).

In the off-season of planting, most of the parameters showed a contrasting pattern from the on-season planting. The increase in the trend of different parameters is more constant for 3 months. The cutting planted with no-treatment showed a relatively lower trend for all parameters as compared to the cutting under different treatments (Fig. 3).

\section{Correlation among various growth parameters}

The pooled data of all three months to analyze the correlation among various growth parameters showed that all the growth parameters were significantly and positively correlated $(P<0.01)$ with each other (Table 7$)$. This positive and significant correlation among all the parameters indicated that improving one variable's performance can trigger the performance of other parameters. The result showed a very strong relationship $(r>$ 0.70 ) of underground biomass with most of the parameters. Aboveground biomass was having a relatively lower correlation $(r<0.60)$ with other variables. The number of sprouts was having a strong relationship with the number of roots $(r=0731)$ and shoot diameter $(r=0.750)$. Length of sprouts and number of leaves were also having a very strong correlation with all the variables, excluding the dry weight of shoot $(r<0.60)$ and shoot diameter $(r<0.40)$. Root length and shoot diameter showed a relatively weaker correlation with each other $(r=0.350)$.

Table 2. Effect of two different planting seasons (February and July) on various growth parameters in 30 DAP.

\begin{tabular}{lcl}
\hline Parameters & F-Statistic & p-value \\
\cline { 1 - 2 } No of Sprouting & 27.389 & .000 \\
No of leaves & 42.278 & .000 \\
Sprouting length & 14.588 & .000 \\
No of Roots / cutting & 41.853 & .000 \\
Root length / cutting & 10.090 & .003 \\
Fresh weight of shoot & 50.435 & .000 \\
Fresh weight of root & 54.450 & .000 \\
Dry Weight of shoot & 0.783 & .382 \\
Dry weight of root & 208.413 & .000 \\
Shoot Diameter & 4.189 & .047 \\
\hline
\end{tabular}



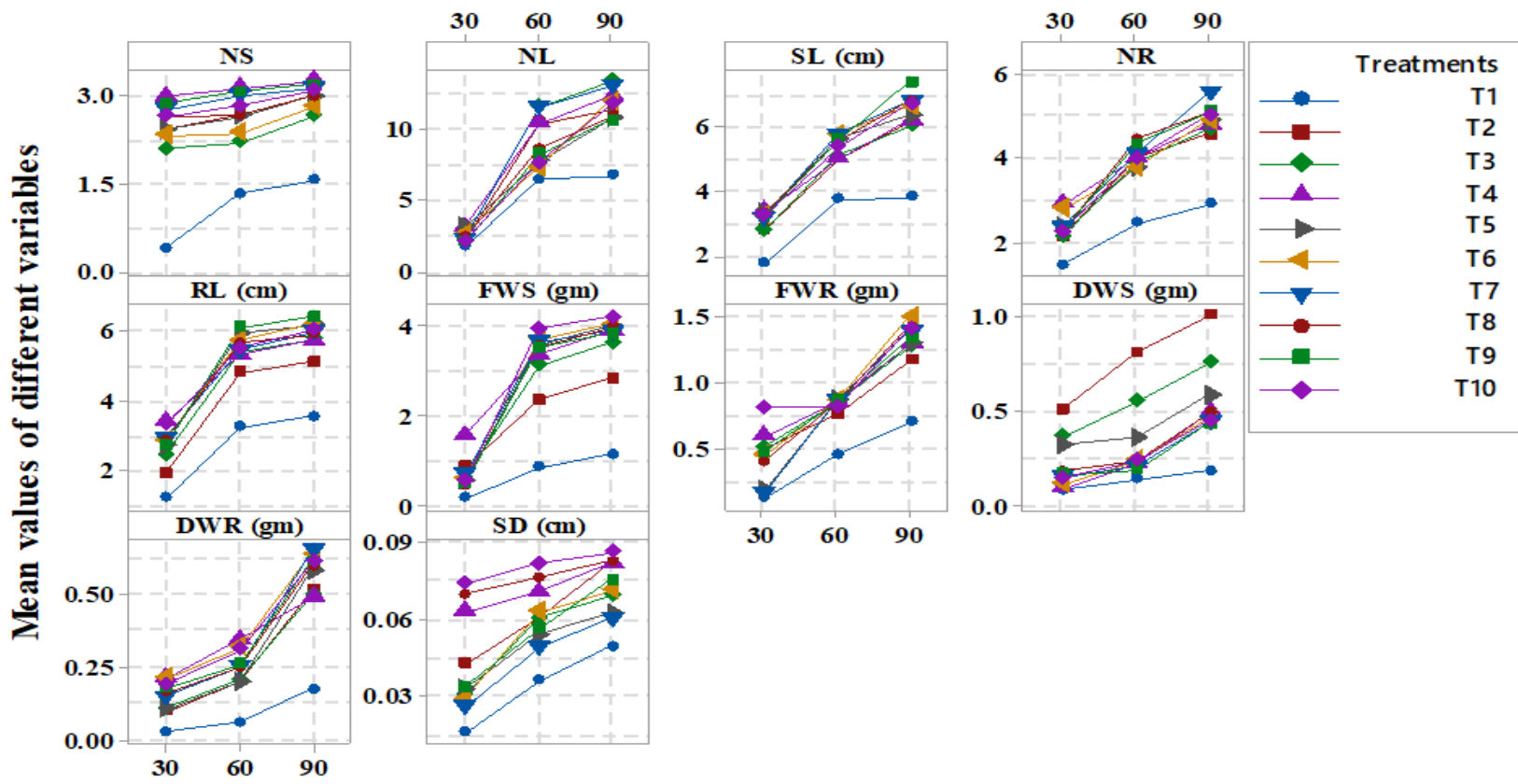

Days

Fig. 2. Trends of various growth parameters in on-season planted cuttings during 3 months of planting. (T1: No Treatment; T2: IBA 100ppm; T3: IBA 200 ppm; T4: IBA 300 ppm; T5: NAA 100ppm; T6: NAA 200 ppm; T7: NAA 300 ppm; T8: GA3 100ppm; T9: GA3 200 ppm; T10: GA3 300 ppm) (NS: Number of Sprouts; NL: Number of Leaves; SL: Sprout Length; NR: Number of Roots; RL: Root Length; FWS: Fresh Weight of Shoot; FWR; Fresh Weight of Root; DWS: Dry Weight of Shoot; DWR: Dry Weight of Root; SD: Shoot Diameter).

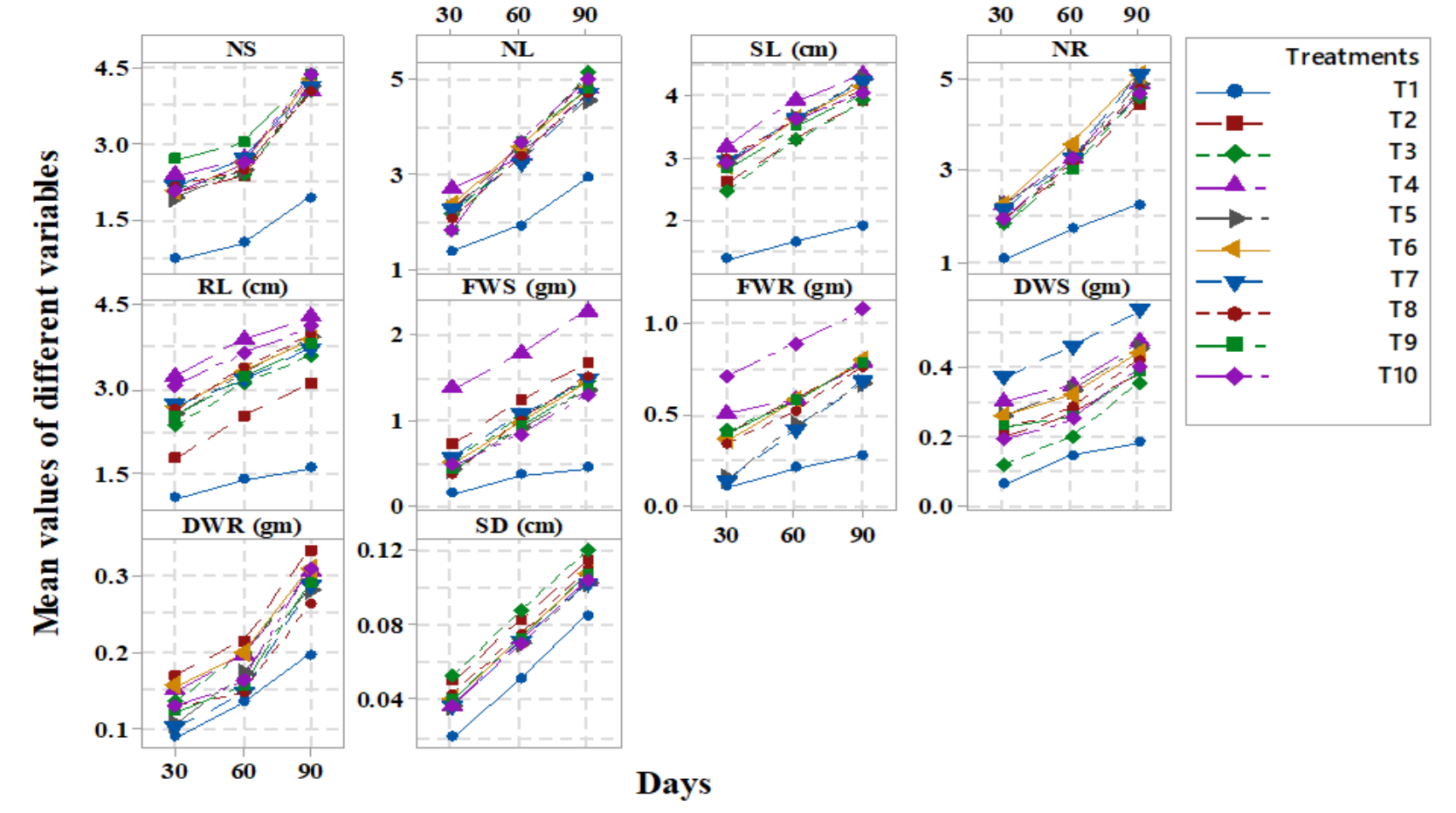

Fig. 3. Trends of various growth parameters in off-season planted cuttings during 3 months of planting. (T1: No Treatment; T2: IBA 100ppm; T3: IBA 200 ppm; T4: IBA 300 ppm; T5: NAA 100ppm; T6: NAA 200 ppm; T7: NAA 300 ppm; T8: GA3 100ppm; T9: GA3 200 ppm; T10: GA3 300 ppm) (NS: Number of Sprouts; NL: Number of Leaves; SL: Sprout Length; NR: Number of Roots; RL: Root Length; FWS: Fresh Weight of Shoot; FWR; Fresh Weight of Root; DWS: Dry Weight of Shoot; DWR: Dry Weight of Root; SD: Shoot Diameter). 


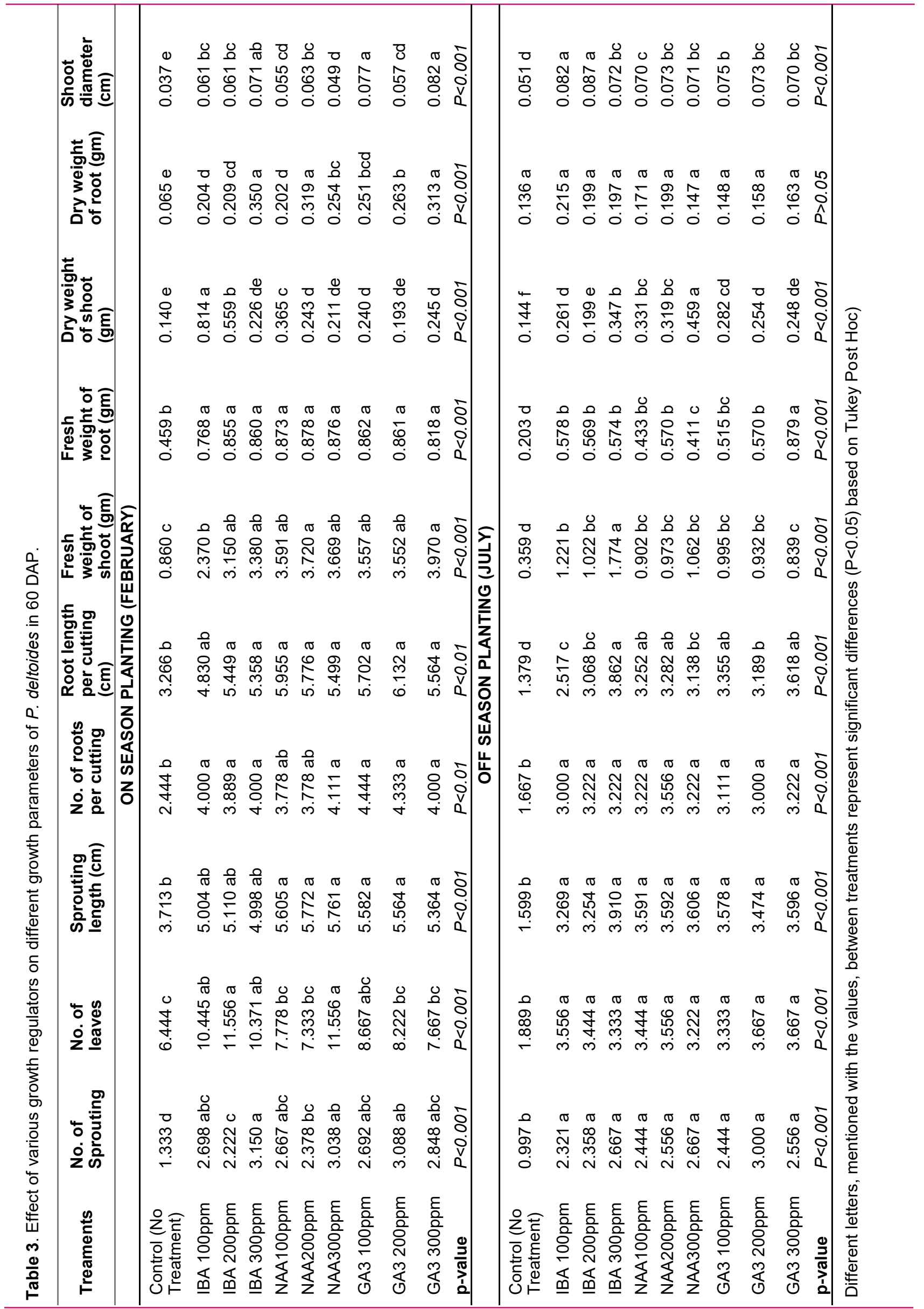


Table 4. Effect of two different planting seasons (February and July) on various growth parameters in 60 DAP.

\begin{tabular}{lll}
\hline Parameters & F-Statistic & p-value \\
\hline No of Sprouting & 9.445 & .004 \\
No of leaves & 711.174 & .000 \\
Sprouting length & 258.551 & .000 \\
No of Roots / cutting & 57.988 & .000 \\
Root length / cutting & 326.908 & .000 \\
Fresh weight of shoot & 643.908 & .000 \\
Fresh weight of root & 280.155 & .000 \\
Dry Weight of shoot & 30.082 & .000 \\
Dry weight of root & 101.231 & .000 \\
Shoot Diameter & 194.348 & .000 \\
\hline
\end{tabular}

\section{DISCUSSION}

Growth regulator is one of the most important factors in affecting the growth performance of stem cuttings. The current study provides evidence of the positive effect of the application of growing media on stem cuttings of $P$. deltoides. Auxins are responsible for the development in plants as they play an important role in cell division expansion (Majda and Robert, 2018). During root formation, the level of auxins in the plants affects the initial cell division (Ludwig, 2000; Kochhar et al., 2005, Perrot-Rechenmann, 2010, Velasquez, 2016). The cuttings, which were not treated with any media, showed comparatively lower values for all growth parameters in both seasons. These responses may have occurred due to the accretion of metabolites at the auxins application position, enlargement of cells, hydrolysis enhancement of carbohydrates, proteins synthesis, and cell division (Strydem and Hartman, 1960). However, IBA was found to be more effective media than NAA and GA3 for most of the parameters in both growing seasons. Phuyal et al. (2018) recorded IBA to be more effective than NAA. They also found an increment in shoot and root parameters of Zanthoxylum armatum with the increase in the concentration of growth hormones. The present study also showed relatively higher values in the higher concentration of IBA and GA3. Meanwhile, in case of NAA treatment, the values for most of the parameters showed no difference or the values of some parameters (No of leaves, sprouting length, No. of roots per cutting, fresh weight of root, dry weight of root $\&$ shoot and shoot diameter) were higher in a lower concentration. Although, these types of responses were mainly observed in initial days of planting (30 DAP).

Several experiments showed the importance of growing media in inducing the roots on stem cuttings (Tchoundjeu et al., 2004, Jacygrad et al., 2012; Usman and Akinyele, 2015, Majeed et al. 2009, Ibironke and
Victor, 2016 and Phuyal et al. 2018). These growing media are well known to have a positive impact on the number of roots per cutting of Azadirachta indica, Aloysia citrodora Cyclopia subternata and Toona ciliate (Gehlot et al., 2014; Ibrahim et al., 2015, Mabizela et al. 2016, Thakur et al. 2018).

IBA was found to be more effective than NAA in increasing root formation. The application of IBA might have caused the vascular differentiation of cells and the production of more number of roots. The high concentration of growth hormones enhanced the length of roots and shoots due to the timely formation of roots and more utilization of the nutrients (Banjara, 2017).

Several researchers have recorded the better rooting ability of IBA at higher concentrations. Majeed et al. (2009) provided IBA at 4000 ppm is the most favourable plant growth regulator for rooting of Aesculus indica. Dalbergia sisso and $D$. latifolia also responded with relatively higher rooting rate with the application of IBA at 5000 ppm (Sharma and Pandey, 1999). High rooting rate was also obtained for Celtis australis cuttings treated with 3000 ppm IBA (Shameet et al. 1989). Thakur et al. (2018) also observed a positive rooting response in the cuttings of Toona ciliate treated with the higher concentration (8000 ppm) of IBA.

In both planting seasons, GA3 was showing a relatively higher value for fresh weight of root in the highest concentration as compare to the other treatments, mainly in initial days of planting. GA3 treatment is mostly used to enhance the growth and vigor of the plants. However, it helps in plant growth and length of internodes by boosting the division and enlargement of plant cells (Dayan et al., 2012; Miceli et al., 2019). Auxins play a key role in the productions of adventitious roots in plants (Davis and Hassig, 1990, Steffens and Rasmussen, 2016; Guan et al., 2019) and also determine the rooting capacity of plants.

NAA is mostly used to induce the longer root system, which may result in less fibrous root system. In the current study, the values for the root parameters under NAA treatments were mostly at par with the maximum values, which provide the evidence of the positive effect of NAA on rooting growth. The studies have also revealed an increment in the rooting of various plant species viz. Taxus wallichiana, Andrographis paniculata, D. sissoo, Hemarthria compressa, with the application of NAA (Kaul, 2008; Yan, 2014; Khudur and Omer, 2015; Hossain, 2016).

\section{Seasonal effect}

The previous studies have shown that the time of collection and planting is an important factor in vegetative propagation of Lippia javanca and Boswellia papyrifera (Soundy et al., 2008; Haile et al., 2011). In the present study, the higher values for most of the root and shoot 


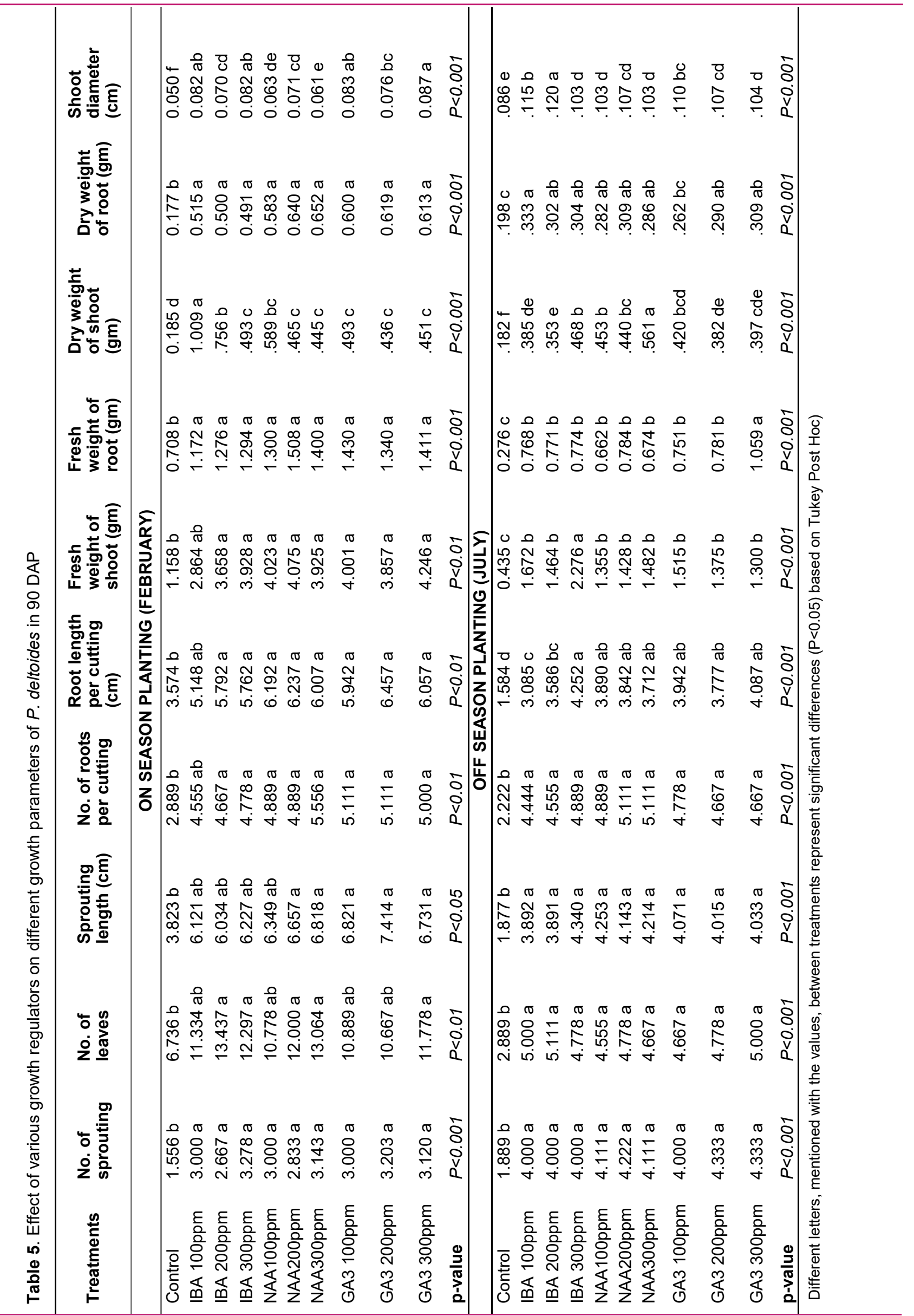


Table 6. Effect of two different planting seasons (February and July) on various growth parameters in 60 DAP.

\begin{tabular}{lll}
\hline Parameters & F-Statistic & p-value \\
\hline No of Sprouting & 128.216 & .000 \\
No of leaves & 462.349 & .000 \\
Sprouting length & 191.280 & .000 \\
No of Roots / cutting & 2.300 & .137 \\
Root length / cutting & 269.904 & .000 \\
Fresh weight of shoot & 318.240 & .000 \\
Fresh weight of root & 314.584 & .000 \\
Dry Weight of shoot & 92.843 & .000 \\
Dry weight of root & 195.931 & .000 \\
Shoot Diameter & 2816.901 & .000 \\
\hline
\end{tabular}

parameters of $P$. deltoides were attained from the cuttings collected and planted in February as compared to cuttings collected and planted in July month. These higher values may have occurred because the accretion of carbohydrates is comparatively higher in the cutting collected during the dry periods due to lower physical activity of donor plants than in the cuttings collected after leaf flushing. Therefore, the mobilization of carbohydrates and other metabolites in very high amounts results in the easier rooting of the cutting collected in February (Haile et al. 2011)

\section{Correlation among growth parameters}

All growth parameters were observed to be significantly $(P<0.01)$ and positively correlated with each other in the cutting planted in both seasons. There was a very strong correlation $(r>0.70)$ recorded for underground biomass and other parameters. This significant and positive correlation among the root and shoot parameters indicated that a possible simultaneous improve- ment could be obtained while selecting one particular trait or another (Dhillon and Singh, 2010). The correlations between these parameters provide a huge benefit to scientists for improving these traits. Many researchers (Tewari et al. 1994; Rawat et al., 2001; Verma and Bangarwa, 2005; Kumar et al., 2017) also established a positive correlation among various growth parameters of $P$. deltoides.

\section{Conclusion}

As sexual propagation is not so much effective in $P$. deltoides, vegetative propagation using stem cutting is thought to be more successful method for mass production of plant material. The study revealed a significant effect of growth hormones on various growth parameters. The highest concentration of IBA and GA3 showed maximum values for most of the growth parameters. These significant effects were observed mainly in 30 DAP, which proved that the growth hormones affected the plant growth mainly in the initial days of the plant's life. On the other hand, collection and planting of the planting material are recommended in February month, as plants showed relatively higher values when planted in dry periods than the plants in the monsoons. The present findings could be of great significance for producing quality plant material of $\mathrm{P}$. deltoides commercially and benefit the Agroforestry systems.

\section{Conflict of interest}

The authors declare that they have no conflict of interest.

\section{REFERENCES}

1. Araya, H. T. (2005). Seed Germination and Vegetative Propagation of Bush Tea (Athrixia phylicoides) (MSc Dissertation) University of Pretoria, Pretoria, South Africa.

Table 7: Significant correlations ( $r$-values) among 6 months growth variables (significant at the $1 \%$ level).

\begin{tabular}{|c|c|c|c|c|c|c|c|c|c|}
\hline $\begin{array}{l}\text { Parameters } \\
(n=180)\end{array}$ & $\begin{array}{l}\text { No. of } \\
\text { Sprouting }\end{array}$ & $\begin{array}{l}\text { No of } \\
\text { leaves }\end{array}$ & $\begin{array}{l}\text { Sprouting } \\
\text { length }\end{array}$ & $\begin{array}{l}\text { No of } \\
\text { roots } \\
\text { per } \\
\text { cutting }\end{array}$ & $\begin{array}{l}\text { Root } \\
\text { length } \\
\text { per } \\
\text { cutting }\end{array}$ & $\begin{array}{l}\text { Fresh } \\
\text { weight } \\
\text { of } \\
\text { shoot }\end{array}$ & $\begin{array}{l}\text { Fresh } \\
\text { weight } \\
\text { of root }\end{array}$ & $\begin{array}{l}\text { Dry } \\
\text { weight } \\
\text { of } \\
\text { shoot }\end{array}$ & $\begin{array}{l}\text { Dry } \\
\text { weight } \\
\text { of root }\end{array}$ \\
\hline No. of leaves & $.287^{\prime \prime}$ & & & & & & & & \\
\hline Sprouting length & $.465^{\star *}$ & $.850^{* *}$ & & & & & & & \\
\hline $\begin{array}{l}\text { No. of Roots per } \\
\text { cutting }\end{array}$ & $.731^{* *}$ & $.722^{* *}$ & $.797^{* *}$ & & & & & & \\
\hline $\begin{array}{l}\text { Root length per } \\
\text { cutting }\end{array}$ & $.448^{* *}$ & $.853^{* *}$ & $.922^{* *}$ & $.778^{* *}$ & & & & & \\
\hline $\begin{array}{l}\text { Fresh weight of } \\
\text { shoot }\end{array}$ & $.361^{* *}$ & $.874^{* *}$ & $.917^{\star *}$ & $.746^{* *}$ & $.923^{* *}$ & & & & \\
\hline $\begin{array}{l}\text { Fresh weight of } \\
\text { root }\end{array}$ & $.490^{* *}$ & $.826^{* *}$ & $.866^{* *}$ & $.797^{\star *}$ & $.839^{* *}$ & $.831^{* *}$ & & & \\
\hline $\begin{array}{l}\text { Dry Weight of } \\
\text { shoot }\end{array}$ & $.426^{\star *}$ & $.585^{\star *}$ & $.538^{* *}$ & $.595^{\star *}$ & $.479^{* *}$ & $.453^{* *}$ & $.545^{* *}$ & & \\
\hline $\begin{array}{l}\text { Dry weight of root } \\
\text { Shoot Diameter }\end{array}$ & $\begin{array}{l}.475^{* *} \\
.750^{* *}\end{array}$ & $\begin{array}{l}.767^{* *} \\
.283^{* *}\end{array}$ & $\begin{array}{l}.832^{* *} \\
.361^{* *}\end{array}$ & $\begin{array}{l}.765^{* *} \\
.702^{* *}\end{array}$ & $\begin{array}{l}.758^{* *} \\
.350^{* *}\end{array}$ & $\begin{array}{l}.795^{* *} \\
.315^{\star *}\end{array}$ & $\begin{array}{l}.871^{* *} \\
.482^{\star *}\end{array}$ & $\begin{array}{l}.523^{* *} \\
.399^{* *}\end{array}$ & $.458^{* *}$ \\
\hline
\end{tabular}


2. Banjara, K., Swamy, S. L. and Singh, A. K. (2017). Vegetative propagation of Terminalia arjuna (Roxb.) WT. \& ARN. by stem cuttings under mist. International Journal of Agriculture Sciences, 9 (50), 4847-4850.

3. Bester, C. (2013). A model for commercialisation of Honeybush tea, an indigenous crop. Acta Horticulturae, 1007, 889-894.

4. Burgess, P. J., Incoll, L. D., Corry, D. T., Beaton, A. and Hart, B. J. (2005). Poplar (Populus spp.) growth and crop yields in a silvoarable experiment at three lowland sites in England. Agroforest Systems, 63, 157-169. https://doi.or g/10.1007/s10457-004-7169-9

5. Chauhan, A. S., Naithani, S., Balodi, K. N., Singh, A. and Khan, R. A. (2015). Effects of Plant Growth Hormones on Populus deltoides Bartram ex Marshall: An Important Species Having Potential in Agro-forestry. Journal of Studies in Dynamics and Change, 2(2), 344-349.

6. Chauhan, S. K., Brar, M. S. and Sharma, R. (2012). Performance of Poplar ( $P$. deltoides Bartr.) and its effect on wheat yield under agroforestry system in irrigated agroecosystem, India. Caspian Journal of Environmental Sciences, 10 (2), 53-60. DOI: 10.18520/cs/v117/i2/219-226

7. Chauhan, V. K., Joshi, A. K. and Dholta, V. K. (2008). Performance of maize (Zea mays L.) varieties under different spacings of poplar (Populus deltoides Marsh.) in lower Western Himalayas. Indian Forester, 134(12): 16031611.

8. Chavan, S. and Dhillon, R. S. (2019). Doubling farmers' income through Populus deltoides-based agroforestry systems in northwestern India: an economic analysis. Current Science, 117(2), 25.

9. Cortizo, S., Bozzi, J., and Mema, V. (2008). A new clone of $P$. deltoides recently released in Argentina. International Poplar commission, Poplers, "Willows and People Well Being", 23rd session, Beijing China, 27-30 October.

10. Dayan, J., Voronin, N., Gong, F., Sun, T., Hedden, P., Fromm, H. and Aloni, R. (2012). Leaf-induced gibberellin signaling is essential for internode elongation, cambial activity, and fiber differentiation in tobacco stems. Plant Cell, 24, 66-79.

11. Davis, T. D. and Haissig, B. E. (1990). Chemical control of adventitious root formation in cuttings. Bull. Plant Growth Regul. Soc. Am., 18:1-17.

12. Dhillon, G. P. S., Singh, A., Singh, P., Sidhu, D. S. (2010). Field evaluation of $P$. deltoides Bartr. ex Marsh. at two sites in Indo-gangetic plains of India. Silvae Genet, 59, 1 7.

13. Dillen, S.Y., Djomo, S. N., Al Afas, N., Vanbeveren, S. and Ceulemans, R. 2013. Biomass yield and energy balance of a short-rotation poplar coppice with multiple clones on degraded land during 16 years. Biomass and Energy, 56, 157-165

14. Fotidar, A. N. (1979). Some observations on poplars in Jammu and Kashmir state. In: Symposium on Silviculture, Management and Utilization of Poplars, Srinagar, 15-18 October 1979. Proceedings. Simla, The Manager Government of India Press.

15. Gehlot, A., Gupta R. K, Tripathi, A., Arya, I., and Arya, S. (2014). Vegetative propagation of Azadirachta indica: effect of auxin and rooting media on adventitious root induction in mini-cuttings. Adv. in For. Sci., 1 (1), 106115.
16. Guan, L., Tayengwa, R., Cheng, Zongming, M., Peer, W. A., Murphy, A. S. and Zhao, M. (2019). Auxin regulates adventitious root formation in tomato cuttings. BMC Plant Biology. 19(1), 1-16

17. Haider, A., Khare, N. and Khan, A. (2015). Performance of poplar cuttings with different growth regulators and potting media. Hort. Flora Research Spectrum, 4 (1), 60-63.

18. Haile, G., Gebrehiwot, K., Lemenih, M. and Bongera, F. (2011). Time of collection and cutting sizes affect vegetative propagation of Boswellia papyrifera (Del.) Hochst through leafless branch cuttings. Journal of Arid Environments, 75, 873-877

19. Henrique, A., Campinhos, E. N., Ono, E. O. and de Pinho, S. Z. (2006). Effect of plant growth regulators in rooting of Pinus cuttings. Braz. Arch. Biol. Tech., 49,189-196

20. Hossain, M. S. and Urbi, Z. (2016). Effect of Naphthalene Acetic Acid on the Adventitious Rooting in Shoot Cuttings of Andrographis paniculata (Burm.f.) Wall. ex Nees: An Important Therapeutical Herb. International Journal of Agronomy, 2006: 6pp. http:// dx.doi.org/10.1155/20 16/1 617543

21. Ibironke, O. A. and Victor, O. O. (2016). Effect of media and growth hormones on the rooting of Queen of Philippines (Mussaenda philippica). J. Hortic., 3, 173. doi:10.4 17 2/2376-0354.1000173

22. Ibrahim, M. E., Mohamed, M. A., and Khalid, K. A. (2015). Effect of plant growth regulators on rooting of lemon verbena cuttings. Material and Environmental Science, 6 (1), 28-33

23. Jacygrad, E., Ilczuk, A, Mikos, M. and Kubiec, K J. (2012). Effect of medium type and plant growth regulators on the in vitro shoot proliferation of Cotinus coggygria Scop. Royal Purple. Acta Sci. Pol. Hortorum Cultus, 11 (5), 143-151

24. Kaul, K. (2008). Variation in rooting behavior of stem cuttings in relation to their origin in Taxus wallichiana Zucc. New Forests, 36, 217-224.

25. Khudhur, S. A. and Omer, T. J. (2015). Effect of NAA and IAA on Stem Cuttings of Dalbergia sissoo (Roxb). Journal of Biology and Life Science, 6(2), 208.

26. Kochhar, V. K., Singh, S. P., Katiyar, R. S., and Pushpangadan, P. (2005). Differential rooting and sprouting behavior of two Jatropha species and associated physiological and biochemical changes. Current Science, 89 (6), 936-939.

27. Kumar, R., Kumari, B., Bhardwaj, K. K., Kumar, A. and Kumar, T. (2017). Study on Growth and Phenotypic Characters of Different Clones of Poplar (Populus deltoides Marsh.) in Nursery. International Journal of Current Microbiology and Applied Science, 6(12): 1840-1848. https:// doi.org/10.20546/ijcmas.2017.612.209

28. Kumar, D., Singh, N. B., Rawat, G. S., Srivastava, S. K., and Mohan, D. (1999). Improvement of $P$. deltoides Bartr. ex Marsh in Indial. Present Status. Indian forester, 125 (3), 245-263.

29. Libby, W. J. (1986). Clonal propagation. J. For., 84(1), 37 $-42$.

30. Ludwig, M. J. (2000). Indole-3-butyric acid in plant growth and development. Plant Growth Regulator, 32, 219-230. doi:10.1023/A:1010746806891

31. Mabizela, G. S., Slabbert, M. M. and Bester, C. (2016). The effect of rooting media, plant growth regulators and clone on rooting potential of honeybush (Cyclopia subter- 
nata) stem cuttings at different planting dates. South African Journal of Botany, 110, 75-79.

32. Majda, M. and Robert, S. (2018). The role of auxin in cell wall expansion. International Journal of Molecular Sciences, 19, 951. doi:10.3390/ijms19040951

33. Majeed, M., Khan, M. A., and Mughal, A. H. (2009). Vegetative propagation of Aesculus indica through stem cuttings treated with plant growth regulators. Journal of Forestry Research, 20 (2), 171-173.

34. Miceli, A., Moncada, A., Sabatino, L. and Vetrano, F. (2019). Effect of gibberellic acid on growth, yield, and quality of leaf lettuce and rocket grown in a floating system. Agronomy, 2019, 9, 382. doi:10.3390/agronomy 9070382

35. Perrot-Rechenmann, C. (2010). Cellular responses to auxin: Division versus expansion. Cold Spring Harb. Perspect. Biol., 2, 1-15.

36. Phuyal, N., Jha, P. K., Raturi, P. P., Gurung, S. and Rajbhandary, S. (2018). Effect of growth hormone and growth media on the rooting and shooting of Zanthoxylum armatum stem cuttings. Banko Janakari, 28 (2), 3-12

37. Rajput, S. S. (1996). Evaluation and utilisation of $P$. deltoides wood - A review. Wood News, 6(3), 28-31.

38. Rawat, G. S., Singh, N. B., Gupta, R. K., Singh, K. and Sharma, S. D. (2001). Clonal evaluation of poplar (Populus deltoides Bartr.) in eastern Uttar Pradesh. INursery testing. Indian Forester, 127 (1), 70-80.

39. Rezende, D. G. S. P., De Rezende, M. D. V. and De Assis, T. F. (2013). Eucalyptus breeding for clonal forestry. In: Fenning TM, editor. Challenges and opportunities for the world's forests in the 21st century. Forestry Sciences, 81, 393-424. doi:10.1007/978-94-007-7076-8_16

40. Sağlam, A. C., Yaver, S., Başer, I. and Cinkiliç, L. (2014). The effects of different hormones and their doses on rooting of stem cuttings in Anatolian sage (Salvia fruticosa mill.). APCBEE Procedia, 8, 348-353.

41. Shameet, G. S., Khosla, P. K. and Kumar, S. (1989). A Preliminary study on rooting of Celtis australis and Punica granulatum cuttings. Indian Journal of Forestry, 12 (4), 321-322.

42. Sharma, L. K., and Pandey, O. N. (1999). Effect of plant growth regulators on rooting behaviour of cuttings of $D a /$ bergia latifolia Roxb. and Dalbergia sissoo Roxb. Indian Forester, 125, 421-426.

43. Singh, K. K., Rawat, J. M. S. and Tomar, Y. K. (2011). Influence of IBA on rooting potential oftorch glory Bougainvillea glabra during winter season. Journal of Horticultural Science \& Ornamental Plants, 3 (2), 162-1656

44. Singh, L. and Singh, A. (2018). Study on performance of poplar clones in relation to soil condition and growth regulator application in nursery. J Phytopharmacol., 7(3),349352.

45. Singh, R. V. (1979). Silvics and ecology of $P$. ciliate-Sym. Proc. Silviculture Management and Utilization of Poplars.Oct. 15-18, 1979. Namager Govt. of India Press. Shimla. Pp 62-6
46. Soundy, P., Mpati, K. W., Du Toit, E. S. (2008). Influence of cutting position, medium, hormone and season on rooting of fever tea (Lippia javanical.) stem cuttings. Medicinal and Aromatic Plant Science and Biotechnology, 2 (2), 114-116.

47. Spriggs, A. C., Dakora, F. D. (2007). Competitive ability of selected Cyclopia Vent. rhizobia under glasshouse and field conditions. Soil Biology \& Biochemistry, 39, 58-67

48. Steffens, B. and Rasmussen, A. (2016). The Physiology of Adventitious Roots. Plant Physiology, 170(2), 603-617.

49. Strydem, D. K., and Hartman, H. T. (1960). Effect of indolebutyric acid and respiration and nitrogen metabolism in Marianna 2624 plum softwood stem cuttings. Proceedings of American Society of Horticulture, 45 (1- 2), 81-82.

50. Tchoundjeu, Z., Ngo Mpeck, M. L., Asaah, E. and Amougou, A. (2004). Therole of vegetative propagation in the domestication of Pausinystalia johimbe (K. Schum), a highly threatened medicinal species of West and Central Africa. Forest Ecology and Management, 188, 175-183.

51. Tewari, S. K., Pandey, D., Pandey, V. and Tripathi, S. (1994). Inter-character correlation in $P$. deltoides Bartr. Indian J. Forest, 17, 61-63

52. Thakur, L., Gupta, T. and Kumar, R. (2018). Effect of growth regulators on sprouting and rooting behaviour in cuttings of Acacia catechu Willd. and Toona ciliata M. Roem. Journal of Pharmacognosy and Phytochemistry. 2018, 109-114

53. Truax, B., Gagnon, D., Fortie, J. and Lambert, F. (2014). Biomass and volume yield in mature hybrid poplar plantations on temperate abandoned farmland. Forests, (5), 3107-3130

54. Ullah, Z., Abbas, S. K. J., Naeem, N., Lutfullah, G., Malik, T., Khan, M. T. U and Khan I. (2013). Effect of indolebutyric acid (IBA) and naphthaleneacetic acid (NAA) plant growth regulaters on Mari gold (Tagetes erecta L.). African Journal of Agricultural Research, 8(29), 4015-4019

55. Usman, I. A. and Akinyele, A. O. (2015). Effects of growth media and hormones on the sprouting and rooting ability of Massularia acuminata (G. Don) Bullock ex Hoyl. Journal of Research in Forestry, Wildlife \& Environment, 7 (2): 137-146

56. Velasquez, S. M., Barbez, E., Kleine-Vehn, J. and Estevez, J. (2016). Auxin and cellular elongation. Plant Physiol., 170.

57. Verma, R. C. and Bangarwa, K. S. (2005). Intercharacter correlation studies in Populus deltoides Bartr. Ex. Marsh. Clones under nursery conditions. Indian Journal of Forestry, 28(4), 359-362.

58. Yan Y. H., Li J. L., Zhang, X. Q., Yang, W. Y., Wan Y, et al. (2014) Effect of Naphthalene Acetic Acid on Adventitious Root Development and Associated Physiological Changes in Stem Cutting of Hemarthria compressa. PLoS ONE , 9(3), e90700. doi:10.1371/journal.pone.0090700

59. Zsuffa, L, Sennerby-Forsse, L, Weisgerber, H., and Hall, R. B. (1993). Strategies for clonal forestry with poplars, aspens, and willows. In: Ahuja MR, Libby WJ, editors. Clonal forestry II. Berlin: Springer; p. 91-119. 